Article

\title{
Physical and Chemical Properties of Waste from PET Bottles Washing as A Component of Solid Fuels
}

\author{
Beata Jabłońska ${ }^{1, * \mathbb{D}}$, Paweł Kiełbasa ${ }^{2}$, Maroš Korenko ${ }^{3}$ and Tomasz Dróżdż ${ }^{2}$ \\ 1 Faculty of Infrastructure and Environment, Institute of Environmental Engineering, \\ Czestochowa University of Technology, Brzeźnicka St. 60a, 42-200 Częstochowa, Poland \\ 2 Faculty of Production and Power Engineering, Agricultural University of Krakow, 31-103 Kraków, Poland; \\ pawel.kielbasa@urk.edu.pl (P.K.); tomasz.drozdz@ur.krakow.pl (T.D.) \\ 3 Department of Quality and Engineering Technologies, Faculty of Engineering, \\ Slovak University of Agriculture in Nitra, Tr. A. Hlinku 2, 94976 Nitra, Slovak Republic; \\ maros.korenko@uniag.sk \\ * Correspondence: bjablonska@is.pcz.czest.pl; Tel.: +48 343250917
}

Received: 1 May 2019; Accepted: 4 June 2019; Published: 10 June 2019

\begin{abstract}
Waste incineration is one of the paths of implementation of the European Union's strategy aimed at reducing the amount of waste deposited in landfills. Along with the development of methods for processing and recycling various wastes, new waste is generated. One example is waste from polyethylene terephthalate (PET) bottles washed during their recycling. In this paper, physical and chemical properties of such wastes are analyzed in terms of their use in the power industry. This research is part of the search for new sources and new technologies for energy production. The study has taken into account the energy properties of waste intended for combustion (calorific value, water content, chemical composition, volatile substances, combustible and non-flammable content). Thermogravimetric analysis of the material tested indicated that the waste is a good source of energy. It was found that the elemental composition $(\mathrm{C}, \mathrm{H}, \mathrm{N}, \mathrm{S}, \mathrm{O})$ of the waste investigated is similar to that for biomass materials, and the calorific value of $13.2 \mathrm{MJ} / \mathrm{kg}$ qualifies the waste for combustion, provided that its initial moisture is reduced, for example, for co-combustion in the cement industry. Another possibility is mixing the waste with other kinds of waste to obtain a new fuel with more satisfactory parameters.
\end{abstract}

Keywords: PET bottles washing; alternative fuel; refuse derived fuel; PET recycling

\section{Introduction}

Synthetic polymers, due to their strength, durability and cheapness, have replaced many natural materials used in various industries [1]. They are often used for packaging production, like bags, foils, bottles and packaging of household chemistry products. Their properties include resistance to salt, alkaline and anaerobic solutions, but they do not show this feature for highly oxidizing substances. They are water-resistant and slightly water-absorbing, and they have high permeability for gas, but low for water vapour [2]. These features make most of the synthetic polymers used also resistant to biodegradation in the natural environment, where they can remain for hundreds years. They can also be transported by living organisms, which consume plastic particles together with food, far from the source, even in the seas and oceans, and therefore they pose a threat to the entire ecosystem [3].

The production of plastics in the world is constantly growing. According to the EPRO (European Association of Plastics Recycling and Recovery Organisations) report [4], global plastics production in 2017 amounted to 348 million Mg and increased by $4 \%$ compared to 2016. With a 19\% share, Europe remains the second largest region in terms of plastic production, second only to China, with a share 
of $29 \%$. The rapid development of the global industry, population growth and steady economic growth in many countries have contributed to the improvement of the quality of life of the population, but one of the consequences of lifestyle improvement is an increase in the quantity of products used, and thus the polymer waste produced each day [5]. The demand for plastics in Europe in 2017 amounted to 51.2 million $\mathrm{Mg}$ (an increase of 1.3 million $\mathrm{Mg}$ in comparison to the previous year) [4]. As a result, the amount of plastic waste increases year by year. For example, the amount of plastic waste collected in the European Union increased from 24.5 million Mg in 2006 to 27.1 million Mg in 2016. Generating such a large amount of polymer waste from used packaging and other products is a serious threat to the natural environment [6].

A priority in contemporary Europe is the rational use of natural resources and ensuring sustainable waste management. The management of plastic waste can be carried out in different ways, most often through recycling, incineration or storage. Due to the long degradation time of the polymer waste, space constraints and pollution of the water and soil environment, they should not end up in landfill. In turn, the combustion of plastics is the reason for the emission of volatile compounds and toxic gases resulting from the decomposition of the polymer chain during combustion. The latter causes air pollution due to emissions of oxides of hydrocarbons, ammonia, sulphur dioxide, corrosive organic acids, dioxins, furans and others [7]. Therefore, the most appropriate form of plastic waste management seems to be mechanical (material) and chemical (raw material) recycling, which results in the same products as the initial product or products for other purposes. In the last decade, recycling of plastics waste in the EU28 (plus Norway and Switzerland) increased by almost $80 \%$ (from 4.7 million $\mathrm{Mg}$ in 2006 to 8.4 million Mg in 2016), while the amount of stored waste was reduced by $43 \%$ [4]. Based on EPRO and NAPCOR (National Association for PET Container Resources) reports [4,8], on average up to $30 \%$ of PET packaging (in Europe and the USA) was recycled. According to the Waste Framework Directive [9], by 2020 the percentage of re-use and recycling in the EU should be at least $50 \%$.

Uniform packaging materials (e.g., PET bottles) are recycled mechanically. This recycling can be applied to plastic with a low degree of contamination. This requires a series of consecutive technological processes, such as: initial sorting, sorting of materials by type and colour, separation of foreign bodies, grinding, milling, washing, drying and production of semi-finished products (PET flakes) from the recovered raw material. In the case of post-consumer waste, material recycling is possible after removal of contaminants (leftover packaging contents, extraneous matter, dirt, labels). PET can be recovered in the recycling process by thoroughly cleaning it beforehand. The process must be so effective that the quality of refined flakes is as high as possible. Unwashed, soiled and contaminated, they are not suitable for processing into new PET material, and may also contain substances potentially harmful to human health [10]. As a result of processes preparing waste plastic for granulation in the washing process line, waste and sub-process waste are generated. Hence, the technologies applied in processing polymer waste are not completely waste-free. The post-process waste produced in this way is a mixture of various organic and inorganic contaminants. It is worth noting that no clear definitions of the resulting waste and methods for their development have been developed so far. However, in order to be able to select the appropriate method for their management, it is necessary first to accurately identify the waste in terms of quality. The increasing restrictions on the use of various types of post-production waste in agriculture, as well as the rehabilitation of degraded areas, have contributed to the increase in the importance of thermal methods in the disposal of this type of waste. Storage of waste at landfills has now become unacceptable. In line with the EU recommendations for sustainable waste management, the aim is to increase the scale of treatment and disposal of all waste, and in the long-term-to close all landfills completely. This means that it is necessary to recognize the composition of the generated waste or its components manufactured in various industrial sectors (including those dealing with the recycling of plastic waste). Some of them could become raw materials for the production of fuels from stable quality waste and be used especially in energy-intensive industries, such as the cement industry or the power industry, but also in metallurgy, the chemical industry and the building materials industry [11]. Fuels produced from waste are categorized as so-called solid recovered 
fuels (SRF) and are much cheaper than traditional fuels (hard coal, lignite), and sometimes even offered with a surcharge. The use of this type of fuel in co-firing processes reduces greenhouse gas emissions, including methane emitted from biodegradable waste fractions during storage. Such waste is considered in some EU countries to be a renewable energy carrier [11-13].

This article examines the physical properties and chemical composition of the waste generated during the process of washing waste plastics coming from the PET bottle recycling plant with a view towards energy recovery in the combustion processes. The energy industry is interested in obtaining fuel with only strictly-defined utility traits and physical-chemical properties. Due to technical and operational requirements, fuel combustion installations used in power plants do not have the possibility to introduce waste of unknown origin and quality characteristics [14]. The quality of waste generated in various branches of industry is therefore of key importance in managing them as independent fuels or components of solid fuels.

\section{Materials and Methods}

\subsection{Material}

The research was carried out on real waste collected from one of the companies recycling PET bottles located in the European Union. The company processes used PET bottles into full-value granules, so-called r-PET, used for thermoplastic production of new packaging (bottles). The company processes around $2000 \mathrm{Mg}$ of plastic waste per month. The technological installation of bottle recycling consists of four technological lines: initial segregation of PET bottles, flaking, cleaning and washing, and granulating. The schematic course of the processes applied in the recycling of PET bottles is shown in Figure 1.

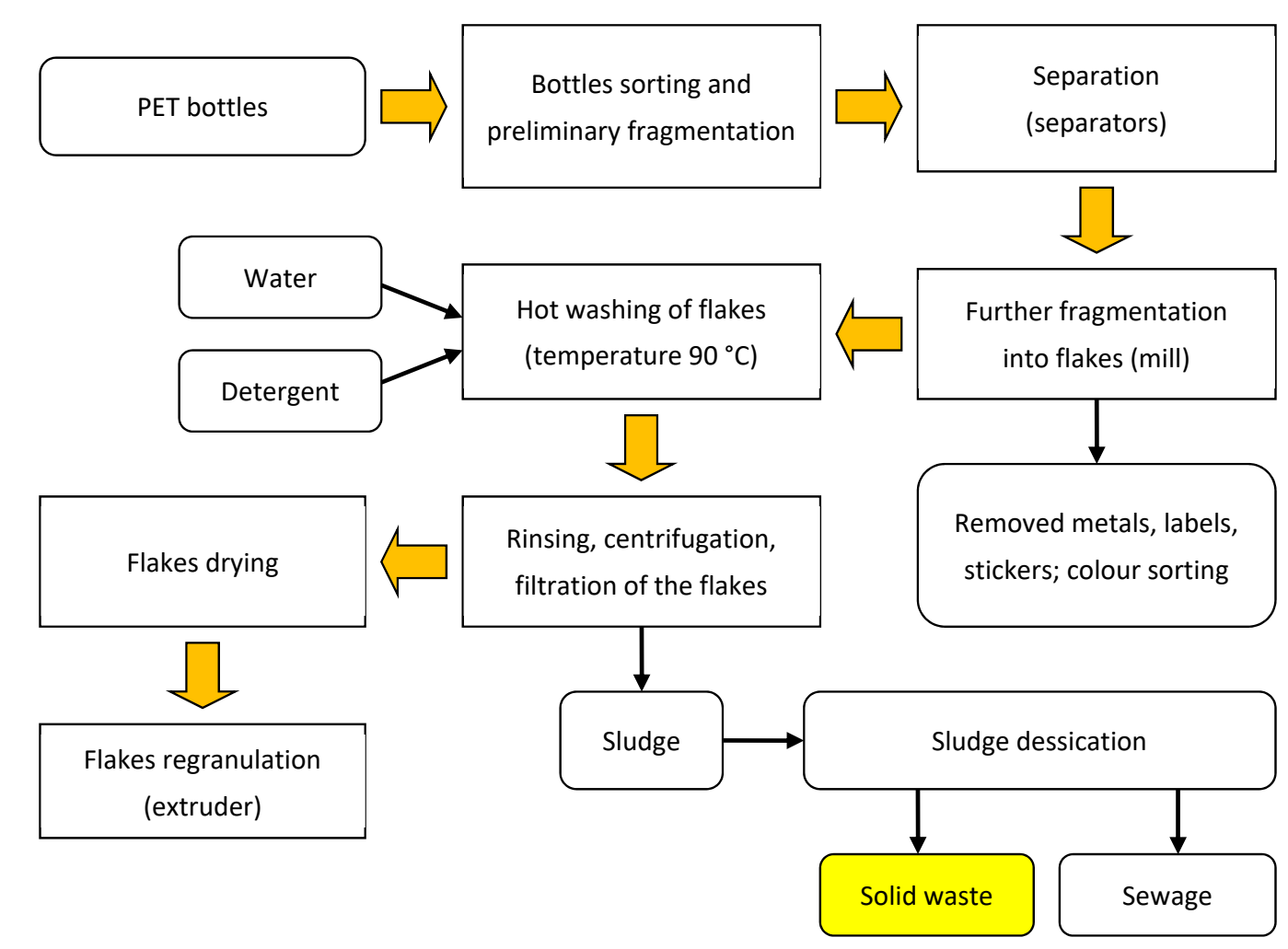

Figure 1. Schematic demonstration of processes used in polyethylene terephthalate (PET) bottle processing during their recycling. The material under investigation is the solid waste marked in yellow.

In the first stage of recycling, the delivered bottles are segregated depending on the type of material, number, colour, processing method and type of product. This process is very important, 
because even a small amount of impurities, such as, for example, PVC (polyvinyl chloride), results in the formation of poor quality PET flakes, making them less attractive as a secondary product. The company uses both manual and automatic segregation, using devices such as metal detectors, colour sorters and ballistic separators.

Then the bottles undergo the process of fragmentation into small flakes by means of cutting mills with a dust collector. The resulting flakes are subjected to a washing process using detergents and caustic soda at a temperature of $90^{\circ} \mathrm{C}$, which allows dirt, glue, natural oils, paper and other impurities to be removed from them. PET flakes from the hydrocyclone drainage system are continuously transferred to the tank of the washing machine (washer). This device has a rotor spinning at a constant speed with a large number of steel tabs, and the friction against flakes at a properly selected retention time is the basis for their washing. The PET flakes floating on the surface of the water are scraped off by a special arm moving along the edges of the tank, while dirt and other impurities fall to the bottom of the tank in the form of waste sludge. As a result of the flotation separation process, the flakes are separated from impurities during washing. The sludge is discharged into the tank, and then filtered and dewatered on the presses. After washing, the flakes are rinsed in scrubbers to remove residual impurities and detergent. The next step is drying the petals. Mechanical and thermal dryers with an injection blower are most often used. The mechanical dryer is used to dry the flakes, while the thermal dryer is used to reduce the moisture on the flakes.

After cleaning and drying, the flakes go to the final stage of recycling, the extruder, which is one of the most important elements in the process of processing polymers. It consists of a heated barrel with an internal rotating screw. As the flakes go into extrusion, they melt due to heat and friction during the flow of viscous and mechanical interactions between the screw and the barrel walls [5]. Then the waste goes to the tub with cooling water and regranulator. The last stage before going to the silos is a vibrating separator rejecting oversized and glued granules. The rejected granules are melted again.

This research was performed on PET bottle washing waste (PETWW) obtained from dehydration on the press (yellow box in Figure 1). The waste resulting from dehydration on the press (Figure 2a) was collected for testing. Samples were taken in accordance with the BN-87/9103-03 standard [15]. 16 individual samples were taken from different locations of the waste batch at the same time using a stainless steel blade. The samples were combined and mixed thoroughly in a plastic container, obtaining approximately $20 \mathrm{dm}^{3}$ of averaged waste. From the averaged sample, 5 laboratory samples were taken (each weighing approximately $1 \mathrm{~kg}$ ), which were immediately tested. The raw waste was dried to air-dry condition at $105^{\circ} \mathrm{C}$ (Figure 2b).

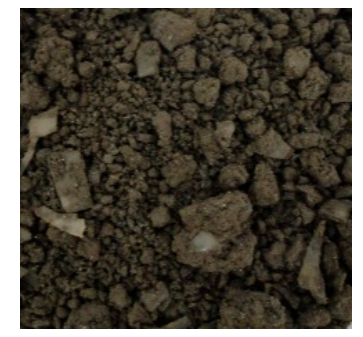

(a)

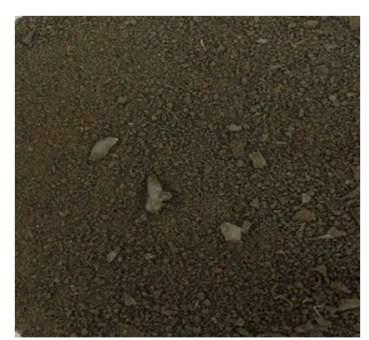

(b)

Figure 2. Raw (a) and dried (b) PET bottle washing waste (PETWW).

The amount of solid waste generated by $1 \mathrm{Mg}$ of PET bottles can only be approximated, because it depends on the quality of the processed PET bottles. The company under consideration processes around $2000 \mathrm{Mg}$ of PET bottles per month and the solid waste obtained is around $119 \mathrm{Mg} / \mathrm{month}$. Hence, it follows that $1 \mathrm{Mg}$ of PET bottles generates around $60 \mathrm{~kg}$ of solid waste under consideration. According to one study [16], $1 \mathrm{~kg}$ of PET requires ca. $3.5 \mathrm{dm}^{3}$ of water, which gives $7000 \mathrm{~m}^{3}$ of sewage per month. Thus, the solid waste fraction is around $1.7 \%$ of sewage generated in the company. 


\subsection{Methods}

The analysis of the physical and chemical properties of PETWW was made in accordance with the applicable standards. Each assay was performed five times, and each series of measurements was carried out in the same way. The research results presented in the tables are the arithmetic mean of the five measurements. The particular physical and chemical analyses were carried out as follows:

- Granulometric composition was determined by sieve analysis, according to [17]. The analysis was performed on waste dried at $105^{\circ} \mathrm{C}$. Separation of the material into fractions containing grains of various sizes was carried out on an AS 300 vibrating screen (Retsch, Germany). The grain uniformity coefficient was calculated using the Hazen formula $U=d_{60} / d_{10}$, where $d_{60}$ is the equivalent diameter corresponding to $60 \%$ of the grains on the summation curve, and $d_{10}$ is the equivalent diameter corresponding to $10 \%$ of the grains on the summation curve [18].

- Hygroscopic, transient and analytical moisture was determined according to the standard [19]. Total moisture was determined as transient moisture plus moisture of air-dry fuel, calculated as a percentage of the weight of the working fuel as follows:

$$
W_{\text {tot }}=W_{\text {tr }}+W_{\mathrm{h}} \frac{100-W_{\text {tr }}}{100}
$$

where: $W_{\text {tot }}$-total moisture (\%), $W_{\text {tr }}$-transient moisture (\%), $W_{\mathrm{h}}$-hygroscopic moisture (\%). To determine the moisture content, a laboratory dryer (SLW 115 STD, POL-EKO) was used.

- The bulk and specific densities were found in accordance with [20] and [21], respectively. The specific density was determined by the pycnometer method as the ratio of the mass and volume of the solid phase. The bulk density found by determining the mass of the sample and the volume occupied by the sample in the measuring vessel [22]. The mass of the sample is the difference in mass of a measuring vessel of a specified volume, filled with freshly made material and an empty vessel.

- The content of total organic substances was determined from the loss on the scale after calcination at a temperature of $500{ }^{\circ} \mathrm{C}$, according to the method used by Skalmowski et al. [21].

- The chemical composition of the inorganic substance was determined using XRF (Philips PW 1404 sequential spectrometer). The ash basicity index was calculated as follows [23]:

$$
B I=\frac{\mathrm{Fe}_{2} \mathrm{O}_{3}(\%)+\mathrm{CaO}(\%)+\mathrm{Na}_{2} \mathrm{O}(\%)+\mathrm{MgO}(\%)+\mathrm{K}_{2} \mathrm{O}(\%)}{\mathrm{SiO}_{2}(\%)+\mathrm{Al}_{2} \mathrm{O}_{3}(\%)+\mathrm{TiO}_{2}(\%)} .
$$

- Leaching tests of trace elements were carried out in accordance with the standard [24]. The test sample was crushed and sieved through a sieve with a mesh size $<10 \mathrm{~mm}$. The tests of leaching of impurities from waste were carried out for the ratio liquid to solid phase $10 \mathrm{l} / \mathrm{kg}$. The individual compounds were designated using the reference methods indicated in [25].

- Sulphates, chlorides, fluorides, sodium and potassium were determined in accordance with the existing standard [26], and substances extracted with petroleum ether (PEE) by the specific method used by Hermanowicz et al. [27]. The determination consisted in subjecting the waste sample to extraction with petroleum ether in the Soxhlet apparatus, and then removing the solvent and weighing the remaining extract. The designation was made for a sample of dried and crushed waste.

- The content of organic compounds in aqueous extracts was determined on an N/C 3100 multi analyzer (Analytik Jena). The analyzer directly measures the total carbon (TC) and the total inorganic carbon (TIC), whereas the total organic carbon (TOC) is determined as the difference between TC and TIC.

- The concentration of metal ions was analyzed using an inductively coupled plasma ICP-AES emission spectrometer (Thermo Elemental IRIS Intrepid II XSP DUO). Before the measurements, 
the waste was subjected to the mineralization process and prepared in the form of solution. Waste samples were pre-dried at $105^{\circ} \mathrm{C}$ and crushed. Next, about $2 \mathrm{~g}$ of the sample were weighed and placed in a porcelain crucible. Samples prepared in this way were burned for 5 hours at $520^{\circ} \mathrm{C}$ in an FCF22S muffle furnace (CZYLOK, Poland). The ash was then dissolved in $20 \mathrm{ml}$ of $\mathrm{HCl}$, poured through a filter into a $100 \mathrm{ml}$ flask and made up to volume with distilled water. Solutions prepared in this way were analyzed for the content of metals.

- Thermal analysis was carried out using a LABSYS TG-DTA/DSC type derivative. A sample of $10 \mathrm{mg}$ was heated under nitrogen to $1000^{\circ} \mathrm{C}$ at a heating rate of $10^{\circ} \mathrm{C} / \mathrm{min}$. The device allowed for simultaneous differential and weight analysis by recording temperature, weight loss curve (TG) and thermogravimetric differential curve (DTG) on one graph, which allowed us to link precisely the duration of analysis, temperature and thermal effects in the sample with quantified weight changes.

- $\mathrm{pH}$ measurements were made with an ELMETRON $\mathrm{pH} / \mathrm{mV} \mathrm{CP}-401 \mathrm{pH}$ meter (accuracy of $+/-0.002 \mathrm{pH})$.

- Fuel properties, such as the content of combustible, non-flammable and volatile components were determined in accordance with [21]. In the determination of flammable $\left(\mathrm{X}_{1}, \%\right)$ and non-flammable $\left(\mathrm{X}_{2}, \%\right)$ components, the samples were calcined at $800^{\circ} \mathrm{C}$ to a constant mass in an FCF22S muffle furnace (CZYLOK, Poland). The content of non-combustible constituents in the samples tested was calculated in relation to the dry mass of waste as follows: $X_{2}=100-X_{1}$. The volatile components content was determined by heating the dried and crushed waste sample for 7 minutes in a closed crucible at $800^{\circ} \mathrm{C}$, in accordance with the standardized method, and then determining the loss of mass under these conditions.

- The combustion heat was determined on an isoperiobolic IKA C 2000 Basic calorimeter, while the calorific value was determined according to [28].

- The contents of the basic elementary components $(\mathrm{C}, \mathrm{H}, \mathrm{N}, \mathrm{S})$ were determined on a LECO Tru/Spec CHNS elemental analyzer.

- The oxygen content was determined by a calculation method based on the difference according to the equation (dry basis):

$$
\mathrm{O}(\%)=100 \%-(\mathrm{Ash}(\%)+\mathrm{C}(\%)+\mathrm{N}(\%)+\mathrm{H}(\%)+\mathrm{S}(\%)) .
$$

\section{Results}

\subsection{Granulometric Analysis}

The raw PETWW is a collection of particles with dimensions and shapes hard to identify. The results of granulometric analysis of PETWW are presented in Figure 3.

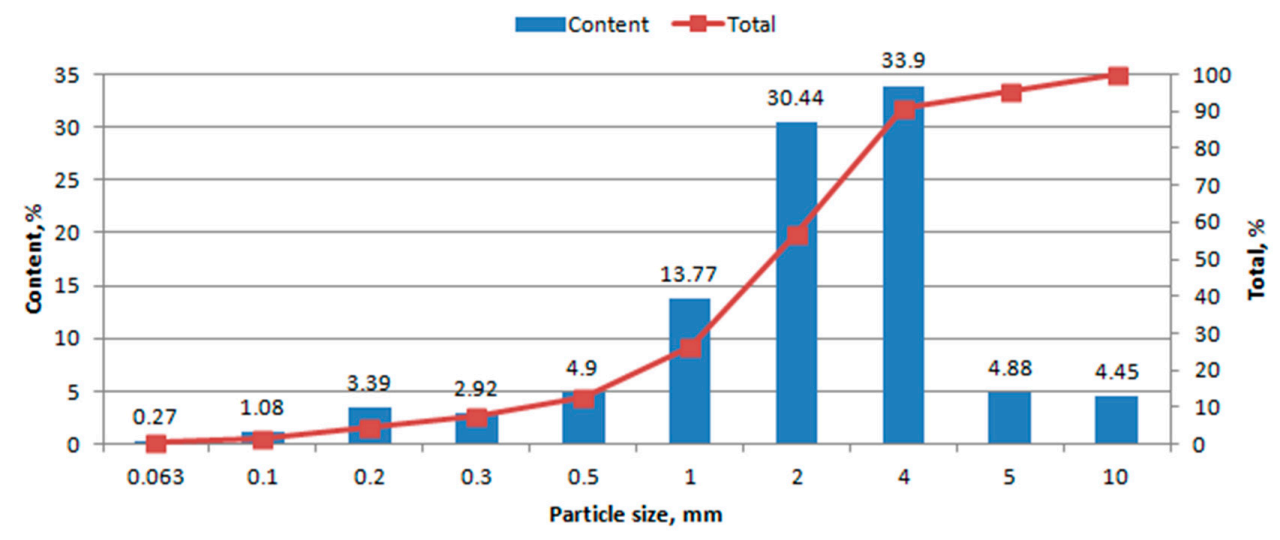

Figure 3. The grain size distribution in PETWW. 
The analysis of the grain composition indicates the presence of three dominant grain classes: $0.063-1 \mathrm{~mm}, 2-4 \mathrm{~mm}$ and $5-10 \mathrm{~mm}$. The percentage share of these classes is $13.8,64$ and $8.9 \mathrm{wt} \%$, respectively. PETWW is a non-homogeneous waste in terms of grain size. This is confirmed by the coefficient of graining uniformity, which is 6.25 .

\subsection{Physical Properties}

The tests of physical properties of PETWW included hygroscopic, transient and total moisture, as well as specific and bulk density. The results of the determinations carried out are presented in Table 1.

Table 1. Physical properties of PETWW.

\begin{tabular}{ccc}
\hline Quantity & Unit & Value \\
\hline Hygroscopic moisture & $\%$ & $43.7 \pm 1.5$ \\
Transient moisture & $\%$ & $6.0 \pm 0.76$ \\
Total moisture & $\%$ & $45.1 \pm 4.03$ \\
Analytical moisture & $\%$ & $12.1 \pm 1.5$ \\
Bulk density & $\mathrm{kg} / \mathrm{m}^{3}$ & $602.3 \pm 63.2$ \\
Specific density & $\mathrm{kg} / \mathrm{dm}^{3}$ & $1.27 \pm 0.14$ \\
\hline
\end{tabular}

The total moisture of PETWW in the working condition was approximately $45 \%$ and is similar to the moisture present in municipal waste and sewage sludge. Mostly, after dehydration on the filter press, sludge is obtained with hydration at a level of approximately $50 \%$. The high value of hygroscopic moisture in the investigated waste of about $44 \%$ is mainly affected by the high presence of organic substances (ca. $34 \mathrm{wt} \%$ ) in the waste, composed of fatty acids, suspension and natural oils, fats and other compounds. The presence of paper and cardboard also represents a large share, whereas the content of small plastic particles in the waste does not affect the moisture of the waste, since they are characterized by low moisture, often even below 1\% [29]. The content of water not related to the organic substance (so-called transient moisture, which can be removed from the waste by drying it at room temperature) is small and amounts to $6 \%$, whereas the moisture content in analytical conditions was $12.1 \pm 1.5 \%$.

The value of the bulk density (volumetric weight) of PETWW is $602.3 \pm 63.2 \mathrm{~kg} / \mathrm{m}^{3}$. It is a value comparable with the density of lignite or wooden pellets [30]. The density of waste depends on the mineral composition of the waste and other admixtures contained in it. The specific density of PETWW determined was $1.27 \pm 0.14 \mathrm{~kg} / \mathrm{dm}^{3}$. This is comparable with the density of polyethylene terephthalate (PET), which is $1.35-1.38 \mathrm{~kg} / \mathrm{dm}^{3}$ [30].

\subsection{Chemical Composition}

The chemical composition of the inorganic substance (ash) from waste is important for the operation of power installations. Its presence in the combustion process affects the melting of slag and the behaviour of ash in convection lines [30]. The chemical composition of PETWW is given in Table 2. The ash basicity index equals 1.44. A particularly high content of $\mathrm{CaO}(16 \%)$ was found.

Table 2. The composition of inorganic substance in PETWW.

\begin{tabular}{ccccccccccccc}
\hline Component & $\mathrm{SiO}_{2}$ & $\mathrm{Al}_{2} \mathrm{O}_{3}$ & $\mathrm{Fe}_{2} \mathrm{O}_{3}$ & $\mathrm{CaO}$ & $\mathrm{Na}_{2} \mathrm{O}$ & $\mathrm{MgO}$ & $\mathrm{K}_{2} \mathrm{O}$ & $\mathbf{P}_{2} \mathrm{O}_{5}$ & $\mathrm{TiO}_{2}$ & $\mathrm{SO}_{3}$ & $\mathrm{MnO}$ & $\begin{array}{c}\text { Loss on } \\
\text { Ignition }\end{array}$ \\
\hline Value, $\mathrm{wt} \%$ & 10.32 & 4.49 & 3.13 & 16.0 & 0.67 & 1.32 & 0.3 & 0.69 & 0.07 & 0.27 & 0.11 & 61.2 \\
\hline
\end{tabular}

All installations for thermal combustion and co-combustion of solid fuels, as well as alternative fuels, must be equipped with monitoring of heavy metal emissions. The content of heavy metals in the raw waste tested was compared with their content in non-flammable parts (ash) and is shown in 
Figure 4. Among the metals tested in the waste, the largest amounts observed were of zinc and barium, chromium, copper, lead and strontium ions (over $100 \mathrm{mg} / \mathrm{kg} \mathrm{d.m.).} \mathrm{Mercury} \mathrm{content} \mathrm{was} \mathrm{below} \mathrm{the}$ limit of quantification.

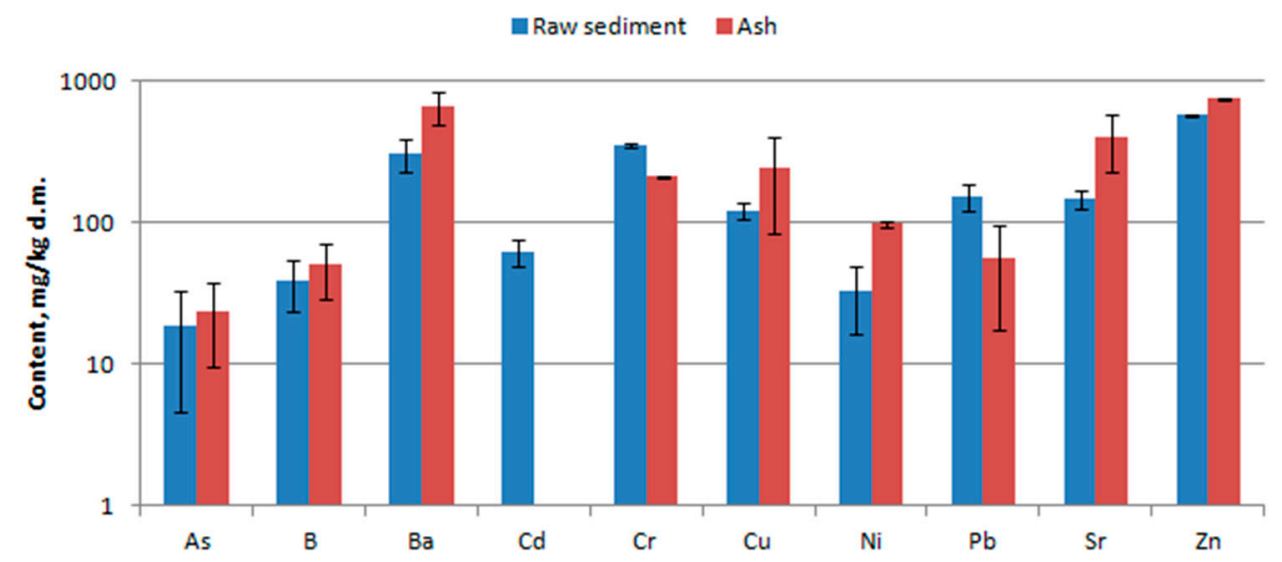

Figure 4. Heavy metals content in PETWW before and after combustion with marked error bars.

\subsection{TG and DTG Analysis}

The thermogravimetric curves of PETWW are presented in Figure 5. On the DTG curve, 5 peaks related to mass loss were identified. The total weight loss of the sample during the calcination process was approximately $58 \%$. At temperatures above $900^{\circ} \mathrm{C}$, combustion in the atmosphere was completed.

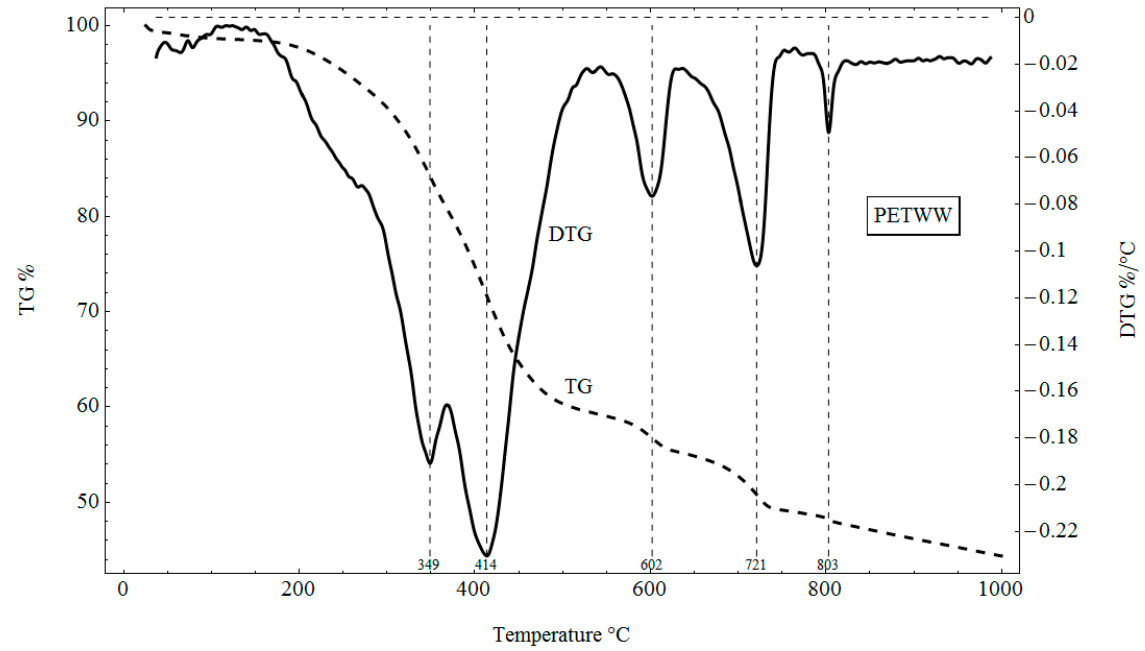

Figure 5. Weight loss curve (TG) and thermogravimetric differential curve (DTG) for the PETWW investigated.

The material tested had undergone a multi-stage decomposition in the temperature range of $200-900{ }^{\circ} \mathrm{C}$. The range of the combustion temperature of the organic substance varies depending on the degree of carbonization within very wide limits. The beginning is between 200 and $250{ }^{\circ} \mathrm{C}$, and the end is between 400 and $1000^{\circ} \mathrm{C}$. The first smooth peak in the DTG curve reflects the process of dehydration, that is, evaporation of the water adsorbed to a temperature of about $150^{\circ} \mathrm{C}$. It was accompanied by an endothermic effect associated with the evaporation of water contained in the sample. Since the samples were stored in the laboratory in dry conditions, where humidity was low, the loss of weight in this situation was quite small. Free water was most likely released during the preparation of the test sample (fragmentation of the fraction less than $0.1 \mathrm{~mm}$ ). Polyethylene terephthalate decomposes in the temperature range of $390^{\circ} \mathrm{C}$ to $490^{\circ} \mathrm{C}$, thus the peak $414^{\circ} \mathrm{C}$ on the DTG curve is most likely 
related to the PET decomposition [31]. The DTG curve also shows an intermediate peak at $349^{\circ} \mathrm{C}$, which corresponds to the decomposition of cellulose and partial decomposition of lignin [32]. These peaks correspond to the largest mass loss (about $44 \%$ ) associated with the release of volatile substances from the combustion of cellulose and plastic. The peak temperatures are widely used as a measure of reactivity [33]. Song et al. [34] obtained a similar temperature distribution range from $330{ }^{\circ} \mathrm{C}$ to $535^{\circ} \mathrm{C}$ in thermogravimetric studies for plastic coastal debris. The third peak on the DTG curve with a maximum of $602{ }^{\circ} \mathrm{C}$ is associated with thermal decomposition reactions of $\mathrm{Ca}(\mathrm{OH})_{2}$, which take place at temperatures of $480-620^{\circ} \mathrm{C}$ [35]. The sample contains approximately $2 \% \mathrm{Ca}(\mathrm{OH})_{2}$. The temperature range at which structural water is released $\left(400-625^{\circ} \mathrm{C}\right)$ partially coincides with the decomposition of organic matter [36]. On the thermal curves (peaks 4 and 5 in Figure 5), the effects associated with the decomposition of carbonates and sulphates $\left(\mathrm{CaCO}_{3}, \mathrm{CaSO}_{4}\right)$ of aluminium salts and chlorides are also clearly visible. This reaction is accompanied by a change in the weight of the sample by $8.5 \%$.

\subsection{Fuel Properties}

The fuel properties of the PETWW investigated are presented in Table 3. The PETWW investigated has a relatively high content of flammable parts $(62 \%)$ and an average ash content of around $38 \%$. The ash content of the waste tested is similar to the ash content determined for digestate sewage sludge $(39.3 \%)$ or charred municipal waste (41.2\%) [30]. The calorific value of the material tested ranges from $10.1 \mathrm{MJ} / \mathrm{kg}$ at a moisture of $48.7 \%$, through $11.7 \mathrm{MJ} / \mathrm{kg}$ at a moisture of $33.6 \%$ to $13.2 \mathrm{MJ} / \mathrm{kg}$ at a moisture of $7.8 \%$.

Table 3. Fuel properties of PETWW in comparison with other solid fuels and recommended values for formed fuels.

\begin{tabular}{|c|c|c|c|c|c|c|}
\hline \multirow[b]{2}{*}{ Parameter } & \multirow{2}{*}{$\begin{array}{l}\text { Tested } \\
\text { PETWW }\end{array}$} & \multirow{2}{*}{$\begin{array}{l}\text { Dry Sewage } \\
\text { Sludge [37] }\end{array}$} & \multirow{2}{*}{$\begin{array}{c}\text { Flame Coal } \\
{[38]}\end{array}$} & \multirow{2}{*}{ Lignite [38] } & \multicolumn{2}{|c|}{ Biomass } \\
\hline & & & & & $\begin{array}{c}\text { Sawdust from } \\
\text { Pine [39] }\end{array}$ & $\begin{array}{c}\text { Wheat } \\
\text { Straw [40] }\end{array}$ \\
\hline The calorific value, $\mathrm{MJ} / \mathrm{kg}$ & $10.1-13.2$ & $12.279-13.503$ & 24.82 & 22.91 & 19.41 & N/A \\
\hline Non-flammable parts (ash), \% & $37.6 \pm 1.75$ & 40.3 & 8.52 & 4.12 & 1.88 & 7.01 \\
\hline $\begin{array}{c}\text { Flammable parts (loss of } \\
\text { ignition), } \%\end{array}$ & $62.4 \pm 1.05$ & 59.7 & 91.48 & 95.88 & 98.12 & 92.99 \\
\hline Volatile matter, $\%$ & $57.7 \pm 4.6$ & N/A & 40.19 & 47.63 & 73.52 & 73.20 \\
\hline \multicolumn{7}{|c|}{ Ultimate, Dry Basis } \\
\hline Carbon, C, \% & $34.4 \pm 1.1$ & 29.7 & 70.54 & 70.23 & 46.48 & 42.61 \\
\hline Hydrogen, $\mathrm{H}, \%$ & $2.9 \pm 0.14$ & 4.81 & 5.28 & 6.25 & 6.15 & 6.34 \\
\hline Sulphur, S, \% & $0.11 \pm 0.01$ & 0.12 & 0.36 & 0.43 & 0.21 & $<0.01$ \\
\hline Nitrogen, N, \% & $0.39 \pm 0.05$ & 4.02 & 2.40 & 0.76 & 1.57 & 0.63 \\
\hline Oxygen, $\mathrm{O}, \%$ & $25.59 \pm 1.1$ & 21.08 & 12.91 & 18.21 & 43.71 & 43.41 \\
\hline $\mathrm{H} / \mathrm{C}$ & 1.04 & 1.94 & 0.90 & 1.07 & 1.59 & 1.69 \\
\hline $\mathrm{O} / \mathrm{C}$ & 0.56 & 0.53 & 0.14 & 0.19 & 0.71 & 0.71 \\
\hline
\end{tabular}

\subsection{Water Extract Analysis}

In order to determine the degree of threat to the environment that the tested waste may pose during storage, analysis of the washing out of impurities was carried out. The results obtained were referred to the limit values contained in the Regulation of the Minister of the Environment (Poland) on the conditions to be met when introducing sewage into waters or to the ground and on substances harmful to the aquatic environment [25] - see Figures 6 and 7. Primary metals and easily leached salts, such as chlorides, sulphates, sodium fluorides and potassium, were identified in the eluates. Due to the presence of organic fats, mineral oils and other organic compounds in the waste tested, total organic carbon (TOC) and petroleum ether extractables (PEE) were also designated. The $\mathrm{pH}$ of the extract tested was 7.4. 


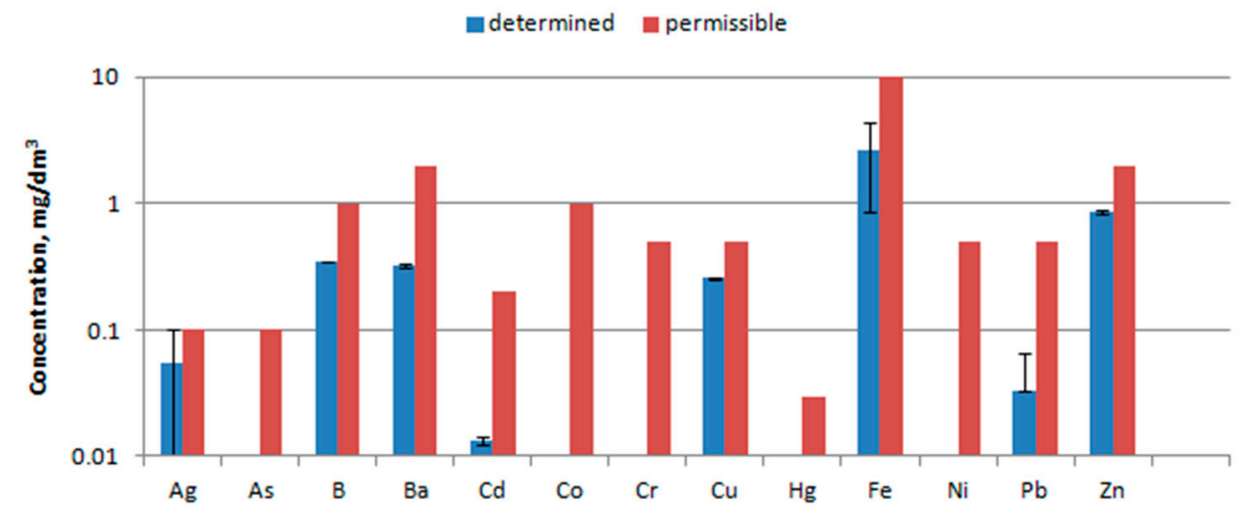

Figure 6. Concentration of heavy metals in PETWW water extract.

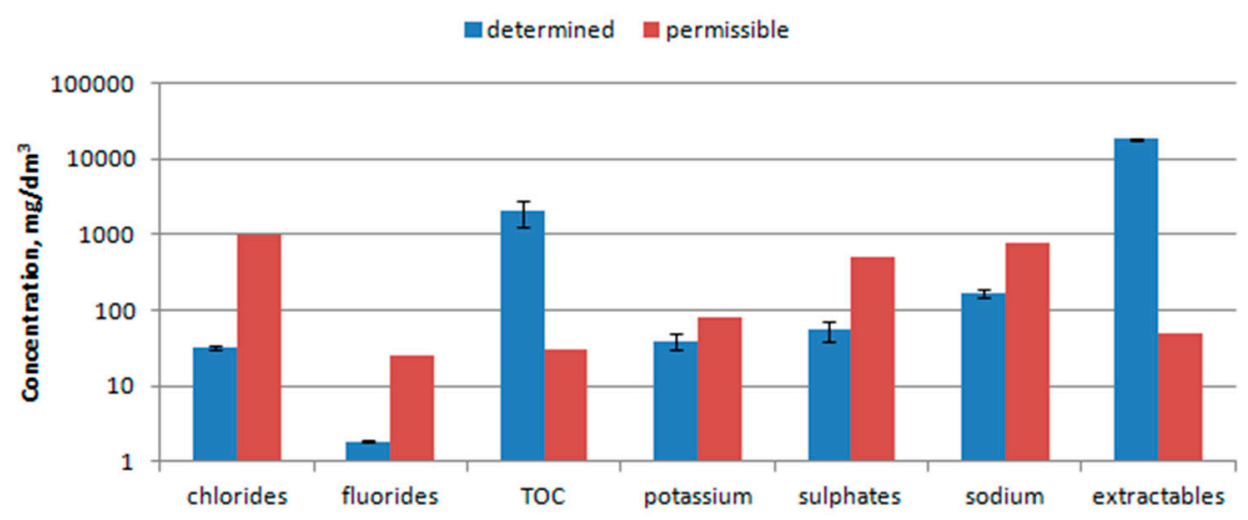

Figure 7. Concentration of ingredients in PETWW water extract.

\section{Discussion}

\subsection{Granulometric Analysis}

Properly determined distribution of waste graining has a major impact on its classification and assessment of suitability for development in the processes of thermal treatment of the waste. According to a previous study [41], waste characterized by granulation below $30 \mathrm{~mm}$ can be used as components of solid fuels. In the energy sector, various technologies of fuel combustion are used, for example, in the technology of co-combustion of waste in fluidized bed boilers an optimally prepared SRF should have a particle size less than $30 \mathrm{~mm}$. The recommended fragmentation of waste for the gasification process for a gasifier with a countercurrent bed is from 5 to $100 \mathrm{~mm}$, with SRF pellets preferred [42]. PETWW can be classified as unevenly grained materials with granulation in the range of 0-10 $\mathrm{mm}$. Hence, the PETWW graining (Figure 3) does not require special preparation for use as a component of solid fuels. However, it should be remembered that each of the technologies of energy use for solid fuels require proper preparation (fragmentation, homogeneity, forming) in order to obtain optimal parameters [43]. For example, the recommended fuel granulation in boilers with a mechanical grate is within the range of $0-25 \mathrm{~mm}$, and it is advisable that the $0-2 \mathrm{~mm}$ fraction should account for no more than $25 \%$ of the total solid fuel stream $[14,43]$.

\subsection{Physical Properties}

Moisture is an important parameter determining the suitability of waste for energetic purposes. High moisture adversely affects the calorific value of waste and the efficiency of the installation due to energy losses on evaporation of water contained in the waste. In the cement industry, where co-combustion of sewage sludge is used, the required content of moisture in sediments is $10-30 \%$. Too much water in the fuel requires auxiliary fuel to sustain combustion. Moisture at a level of 50-65\% 
is usually accepted for biomass, but with such a high water content, combustion is incomplete and causes the formation of a large amount of carbon monoxide [44]. Hence, it follows that the raw PETWW could require some drying to decrease its initial moisture. However, drying is a long and energy-consuming process, which depends on many factors, like temperature, air flow, air humidity and contact area. Therefore, mixing with other waste could be more beneficial to obtain a new fuel with lowered moisture.

The PETWW density and corresponding fragmentation enable good mixing with air. However, in the case of storage, these parameters constitute the output (estimated) accumulations of waste weight, which translates into proper planning and management of this waste.

\subsection{Chemical Composition}

PETWW contains a relatively large amount of calcium (Table 2). Calcium content that is too high is undesirable in the case of waste incineration in power boilers, due to the corrosion of power equipment and the formation of deposits on the surface of boilers [45]. However, in the case of waste incineration in the cement industry, the presence of $\mathrm{CaO}$ is desirable, because in co-combustion technology, $\mathrm{CaO}$ is often added to incinerated waste to neutralize hazardous substances. Another argument to use the waste in co-combustion is its high basicity index (1.44). According to [23], basicity index above 0.5 indicates a possibility of slagging/fouling during standalone combustion; therefore co-combustion with other fuels of a smaller basicity index is reasonable.

The content of metals in the waste (Figure 4) most probably results from washing them out from dyes used in the production of printing inks. Cadmium is also added to plastic products as a dye in the form of organometallic compounds. According to one study [46], zinc may also come from thermal stabilizers used in the processing of polymers that tend to decompose at processing temperatures. The behaviour of individual metals during combustion depends on the combustion conditions and their volatility [47]. After the combustion process, the heavy metals examined were found in the ash in general in amounts higher or comparable to the content in the raw waste (Figure 4). The exception is cadmium, which most likely remained in the gas phase and condensed in the cooler parts of the kiln system. There was also a smaller amount of $\mathrm{Pb}$ and $\mathrm{Cr}$ observed in the ash-similarly to $\mathrm{Cd}$, these metals are also of limited volatility.

The content of heavy metals in PETWW was compared with the quality requirements for alternative fuels in the cement industry [48] and the requirements of the European Association of Cement Producers (group in Lafarge) $[49,50]$. The content of heavy metals in the waste indicates that the limit values included in the guidelines for alternative fuels will not be exceeded (Table 4).

Table 4. The content of heavy metals in PETWW and the limit values required for alternative fuels in cement plants and requirements of the European Association of Cement Producers (EACP).

\begin{tabular}{cccc}
\hline Parameter & Tested PETWW & EACP Guidelines & $\begin{array}{c}\text { Domestic Cement } \\
\text { Plants Requirements } \\
\text { for Refuse Derived Fuel }\end{array}$ \\
\hline $\begin{array}{c}\mathrm{Hg}, \mathrm{mg} / \mathrm{kg} \mathrm{d.m.} \\
\text { The total for } \mathrm{Cd} \text { and } \mathrm{Tl}, \mathrm{mg} / \mathrm{kg} \mathrm{d} . \mathrm{m} .\end{array}$ & 0 & $<10$ & $<2000$ \\
$\begin{array}{c}\text { The total of the remaining metals (As, B, Ba, } \\
\mathrm{Cr}, \mathrm{Cu}, \mathrm{Fe}, \mathrm{Ni}, \mathrm{Pb}, \mathrm{Sr}, \mathrm{Zn}), \mathrm{mg} / \mathrm{kg} \mathrm{d} . \mathrm{m} .\end{array}$ & $1677-1817$ & $<100$ & \\
\hline
\end{tabular}

\subsection{TG and DTG Analysis}

TG/DTG analysis for PETWW indicated that the waste contains several compounds able to use as fuel. The sample was found to contain about $44 \%$ organic matter, $2 \% \mathrm{Ca}(\mathrm{OH})_{2}$ and about $8 \%$ carbonates, aluminium salts and chlorides. The dominant compounds in this waste were cellulose, hemicellulose and PET; therefore thermal decomposition already occurs at a temperature of $300-500{ }^{\circ} \mathrm{C}$. The content of organic matter (including plastic and cellulose) is important from the point of view of the utilization of post-production waste in various branches of industry. Another important property of the 
material tested, determined by thermal analysis, is the presence of calcium and sulphate compounds. The acidic residues present in the inorganic substance (e.g., $\mathrm{CO}_{\text {or }} \mathrm{SO}_{3}$ ) confirm the presence of both carbonates and sulphates such as $\mathrm{CaCO}_{3}$ or $\mathrm{CaSO}_{4}$.

\subsection{Fuel Properties}

In the process of heating solid fuels, certain amounts of vapours, gases and tars are emitted, which are formed as a result of thermal decomposition of solid fuel without access of air. Volatile parts belong to very characteristic features of solid fuels, they decide among other things about the ease of fuel ignition (the higher the volatile content in the fuel, the easier ignition and faster combustion). The PETWW tested is characterized by about $62 \%$ of flammable parts and volatile parts, which indicates a high content of flammable substances. These values are comparable to those for sewage sludge and biomass. According to [30], in the digestate sewage sludge, the content of combustible parts is ca. $60 \%$, and in cotton stalks, $63 \%$. The high content of volatile components is related, among others, to high content of substances extractable with petroleum ether $\left(18,500 \mathrm{mg} / \mathrm{dm}^{3}\right)$. This suggests that from the point of view of process kinetics, the combustion of this type of material will most likely occur mainly in the gas phase, with a slight contribution of the heterogeneous gasification process of char [51].

The basic parameter that clearly specifies the fuel's utility value in the context of technological use is its calorific value. This determines the profitability of use of the material as a fuel. According to the standard used in a previous study [52], the calorific value of solid recovered fuel (in working conditions) is as follows: $\geq 25 \mathrm{MJ} / \mathrm{kg}$ in class $1, \geq 20 \mathrm{MJ} / \mathrm{kg}$ in class $2, \geq 15 \mathrm{MJ} / \mathrm{kg}$ in class $3, \geq 10 \mathrm{MJ} / \mathrm{kg}$ in class 4 , and $\geq 3 \mathrm{MJ} / \mathrm{kg}$ in class 5 . The calorific value of the post-production waste analyzed is in the range 10.1-13.2 MJ/kg (Table 3), therefore the waste can be assigned only to class 4 on the basis of the calorific value. In comparison with other popular solid fuels, the value obtained is around half of the calorific value of high-quality hard coal $(24.5-40.92 \mathrm{MJ} / \mathrm{kg})$. On the other hand, it is comparable to the heating value for sewage sludge, although noticeably less than that of peat, wood or other biomass materials $[37,53,54]$.

The calorific value obtained results from moisture and the composition of the waste tested, the content of cellulose, lignin and PET plastic particles, among others. This makes it possible to use it when co-firing with conventional fuel. In addition, the high content of ligno-cellulosic components and PET particles in the waste makes them suitable as a fuel component. The growing demand for energy poses a threat of depletion of conventional fuel sources; therefore the use of secondary fuel from waste will be one of the most important renewable energy sources. The calorific value of the PETWW tested is above $10 \mathrm{MJ} / \mathrm{kg}$, which gives a possibility of its use as a fuel after reducing the initial moisture $(45 \%)$. It can be reduced to less than $30 \%$ by drying it; however, drying processes are expensive and often only cost-effective for larger plants. Another method of reducing the water content is to mix the waste with other dry waste and additives that will bind moisture from PETWW to obtain a plastic or semi-solid consistency. Such a consistency would allow pelletizing and briquetting the final product with low moisture content and high calorific value. In this way it is possible to obtain a composite fuel with specific properties (high calorific value and significantly lower hydration). It is therefore proposed to convert waste into an alternative fuel form using other appropriately selected waste, for example, paper, cardboard, rubber, plastic, textiles, waste charcoal, sludge from other industries and other binding substances (e.g., lime, coal tar pitch, polyvinyl alcohol, starch and modified cellulose). In such a fuel, an appropriate calorific value, as well as a specific chemical composition, may be achieved, including trace constituents adversely affecting the boiler's operation or exceeding the permissible limits of pollutant emissions into the air. The energy valorisation of waste through the generation of fuels with stable quality parameters allows them to be energy-efficient and safe for environmental use.

The content of the basic elements in the waste tested is close to the value that is obtained for biomass (Table 3), wherein there is less carbon, hydrogen and oxygen, which translates into a lower heating value. The carbon content is about $70 \%$ of that observed in biomass, but slightly larger than in the case of dry sewage sludge. There is little hydrogen in the tested waste-about half the value 
observed in biomass, coal and lignite. The oxygen content is comparable to that determined for biomass. The molar mass $\mathrm{H} / \mathrm{C}$ ratio is 1.04 , similarly to hard and brown coal. The molar mass ratio $\mathrm{O} / \mathrm{C}$ equals 0.56 , which is close to that observed for biomass. It is worth noting that the waste tested contains relatively little sulphur and nitrogen. This is particularly evident in the case of nitrogen, whose content in the tested waste is the lowest of the fuels presented in Table 3. The elemental composition of the PETWW examined does not differ significantly from biomass and sewage sludge, and the low content of $\mathrm{S}$ and $\mathrm{N}$ elements (below 1\%) is beneficial due to the emission of sulphur and nitrogen oxides during thermal processes.

In the ash examined, a significant amount of calcium oxides (16\%) and also magnesium $(1.32 \%)$ was found (Table 2), which indicates the strongly alkaline properties of these materials. For this reason, they can be used as $\mathrm{pH}$ neutralizers, for example, for sewage sludge [55], or for de-acidification of soils [56]. However, the high levels of barium, chromium, copper zinc, nickel and strontium present in the ash (Figure 4) may be a factor limiting their use as a source of these elements for soils. Silicate-aluminium ashes, thanks to the high content of lime, are suitable for the production of road binders, allowing soil stabilization. The use of ash allows for a significant reduction of the binder's cost while obtaining the same stabilization parameters that are obtained using pure lime or cement [57]. Among other currently-used directions for the management of ashes from the combustion of coal or biomass, attention should be paid to the production of building materials [58] and road construction for making road foundations [59]. Interesting possibilities are the use of ashes for wastewater treatment [60], as absorbents [61], or in preparation of zeolites [62]. The use of ashes from the combustion of PETWW waste, however, requires additional research in terms of assessing their suitability or inconvenience for the aquatic environment.

\subsection{Water Extract Analysis}

No limit values in the examined eluates were exceeded in relation to heavy metal ions (Figure 6) as well as chloride, fluoride, sulphate, sodium and potassium ions (Figure 7). Arsenic, cobalt, chromium, mercury and nickel ions were not found, and cadmium and lead ions were found in trace amounts. Small amounts of the remaining metals most likely came from dyes on labels removed from the bottles. The biggest exceedances concerned PEE, the value of which exceeds 300 times the permissible value. Similarly, TOC in the water extract significantly exceeded the permissible value (by about 70 times), which indicates a very high content of organic compounds in the waste. Despite the small amount of heavy metal ions, the wastes tested do not meet the criteria determining the possibility of storing them in a landfill other than hazardous or inert wastes due to the over-normative content of PEE and TOC. Moreover, pursuant to Polish law [63], the waste cannot be disposed of via landfill of non-hazardous and inert waste, if TOC $>5 \%$ d.m., loss on ignition $>8 \%$ d.m. and the heat of combustion $>6 \mathrm{MJ} / \mathrm{kg}$ d.m., which is the case.

\section{Conclusions}

Based on the performed analyses, the following conclusions can be formulated:

1. PETWW is a specific waste, which has the potential to be used as a component of alternative fuels, being a source of renewable energy in combustion processes-it is suitably well grained (grain size up to $10 \mathrm{~mm}$ ), does not contain have heavy metals or other harmful substances in values exceeding the permissible ones, and its calorific value, although noticeably less than that of biomass, is comparable to that of sewage sludge.

2. The calorific value is above $10 \mathrm{MJ} / \mathrm{kg}$ and can reach up to $13.2 \mathrm{MJ} / \mathrm{kg}$ for PETWW of moisture content below $8 \%$. Although low moisture can be cost-ineffective, $10 \mathrm{MJ} / \mathrm{kg}$ at moisture of $45 \%$ can be assumed to be quite good. However, it is suggested that the wet waste should be mixed with other waste to obtain a new fuel with more satisfactory parameters. 
3. The waste should not be disposed in landfill due to values of TOC (ca. $2000 \mathrm{mg} / \mathrm{dm}^{3}$ ), PEE (ca. $18,500 \mathrm{mg} / \mathrm{dm}^{3}$ ) and its quite good calorific value (above $10 \mathrm{MJ} / \mathrm{kg}$ ).

4. PETWW could be used as a fuel in co-combustion processes in energy-intensive industries, for example, the cement industry, which could, however, require some drying or mixing with other fuel.

Author Contributions: Conceptualization, B.J.; methodology, B.J.; validation, P.K. and M.K.; investigation, B.J.; writing—original draft preparation, B.J.; writing—review and editing, B.J. and T.D.; visualization, B.J.

Funding: The APC was funded by the Faculty of Production and Power Engineering, Agricultural University of Krakow.

Acknowledgments: This research was financially supported by the Institute of Environmental Engineering, Częstochowa University of Technology under BS/PB-400/301/19, and the Faculty of Production and Power Engineering, Agricultural University of Krakow.

Conflicts of Interest: The authors declare no conflict of interest. The funders had no role in the design of the study; in the collection, analyses, or interpretation of data; in the writing of the manuscript, or in the decision to publish the results.

\section{References}

1. Vijaykumar, S.; Patel, M.R.; Patel, J.V. Pet waste management by chemical recycling: A review. J. Polym. Environ. 2010, 18, 8-25.

2. Cichy, J.; Sobczyk, W. Odpady z tworzyw sztucznych i ich recykling (Plastics waste and its recycling). Edukac. Tech. Inform. 2014, 1, 348-353.

3. Li, W.C.; Tse, H.F.; Fok, L. Plastic waste in the marine environment: A review of sources, occurrence and effects. Sci. Total Environ. 2016, 566-567, 333-349. [CrossRef] [PubMed]

4. Plastics Europe. Plastics Europe-The Facts 2018; EPRO Report; Plastics Europe: Frankfurt, Germany, 2018; Available online: https://www.plasticseurope.org/de (accessed on 11 March 2019).

5. Seebaluck, V.; Koussa, W.B. Prospects for recycling of waste PET bottles in Mauritius. Univ. Maurit. Res. J. 2009, 15, 334-349.

6. Czarnecka-Komorowska, D. Aspekty recyklingu tworzyw sztucznych. Recykling 2007, 4, 30-31.

7. Katami, T.; Yasuhara, A.; Okuda, T.; Shibamoto, T. Formation of PCDDs, PCDFs, and coplanar PCBs from polyvinyl chloride during combustion in an incinerator. Environ. Sci. Technol. 2002, 36, 1320-1324. [CrossRef] [PubMed]

8. NAPCOR. Report on Postconsumer PET Container Recycling Activity in 2017; NAPCOR Report; NAPCOR: Charlotte, NC, USA, 2017; Available online: https://napcor.com/reports-resources/ (accessed on 11 March 2019).

9. European Parliament; The Council of the European Union. Directive (EU) 2018/851 of the European Parliament and of the Council of 30 May 2018 amending Directive 2008/98/EC on waste. Off. J. Eur. Union 2008. Available online: https://eur-lex.europa.eu/legal-content/EN/TXT/PDF/?uri=CELEX:32018L0851\&from=EN (accessed on 4 June 2019).

10. Krehula, L.K.; Siročić, A.P.; Dukić, M.; Hrnjak-Murgić, Z. Cleaning efficiency of poly (ethylene terephthalate) washing procedure in recycling process. J. Elastomers Plast. 2012, 45, 429-444. [CrossRef]

11. Wasielewski, R.; Sobolewski, A. Stałe paliwa wtórne - jako element systemu odzysku energii z odpadów. Nowa Energia 2009, 1, 24-29.

12. Guo, F.; Zhong, Z. Optimization of the co-combustion of coal and composite biomass pellets. J. Clean. Prod. 2018, 185, 399-407. [CrossRef]

13. Wang, T.; Hou, H.; Ye, Y.; Rong, H.; Li, J.; Xue, Y. Combustion behavior of refuse-derived fuel produced from sewage sludge and rice husk/wood sawdust using thermogravimetric and mass spectrometric analyses. J. Clean. Prod. 2019, 222, 1-11. [CrossRef]

14. Sobolewski, A.; Wasilewski, R.; Stelmach, S. Wykorzystanie stałych paliw wtórnych w energetyce (Utilization of solid recovered fuels in power industry). Polityka Energetyczna 2007, 10, 379-389. 
15. Polish Std. BN-87/9103-03. Unieszkodliwianie Odpadów Miejskich-Pobieranie, Przechowywanie i Przesyłanie Oraz Wstẹpne Przygotowywanie Próbek Odpadów do Badań. Available online: http://bc.pollub.pl/dlibra/publication/ 11242/edition/10220/content?ref=desc (accessed on 6 June 2019).

16. Perugini, F.; Mastellone, M.L.; Arena, U. A life cycle assessment of mechanical and feedstock recycling options for management of plastic packaging wastes. Environ. Prog. 2005, 24, 137-154. [CrossRef]

17. Polish Std. PN-EN 15415-1. State Paliwa Wtórne-Oznaczanie Rozkładu Wielkości Ziaren-Część 1: Metoda Przesiewania dla Czastek o Małym Rozmiarze; Wydawnictwa Normalizacyjne: Warszawa, Poland, 2011.

18. Pazdro, Z.; Kozerski, B. Hydrologia Ogólna; Wydawnictwo/Geologiczne: Warszawa, Poland, 1990; pp. 93-95.

19. Polish Std. PN-80G/04511. Paliwa stałe-Oznaczanie Zawartości Wilgoci; Wydawnictwa Normalizacyjne: Warszawa, Poland, 1980.

20. CEN/TS 15401 Standard. Solid Recovered Fuels_Determination of Bulk Density; BSI Group: London, UK, 2010.

21. Skalmowski, K.; Wolska, K.; Pieniak, U.; Roszczyńska, I. Badania Właściwości Technologicznych Odpadów Komunalnych:Ćwiczenia Laboratoryjne; Oficyna Wydawnicza-Politechnika Warszawska: Warszawa, Poland, 2004; pp. 94-97.

22. Vassilev, S.; Vassileva, C.G.; Karayigit, A.; Bulut, Y.; Alastuey, A.; Querol, X. Phase-mineral and chemical composition of composite samples from feed coals, bottom ashes and fly ashes at the Soma power station, Turkey. Int. J. Coal Geol. 2005, 61, 35-63. [CrossRef]

23. Dyjakon, A. Analysis of slagging and fouling propensities of biofuels in terms of their combustion and co-combustion in the boilers. Agric. Eng. 2012, 2, 5-18.

24. Polish Std. PN-EN 12457-4. Charakteryzowanie Odpadów-Wymywanie-Badanie Zgodności w Odniesieniu do Wymywania Ziarnistych Materiałów Odpadowych i Osadów; Wydawnictwa Normalizacyjne: Warszawa, Poland, 2006.

25. Minister of Environment (Poland). Regulation of the Minister of Environment of 18th November 2014 on the Conditions to be Fulfilled When Introducing Sewage into Waters or into the Ground, and on Substances Particularly Harmful to the Aquatic Environment; (In Polish: Rozporządzenie Ministra Środowiska z dnia 18 listopada 2014 r. w sprawie warunków, jakie należy spełnić przy wprowadzaniu ścieków do wód lub do ziemi, oraz w sprawie substancji szczególnie szkodliwych dla środowiska wodnego, Dz.U. 2014 poz. 1800); Minister of Environment: Warsaw, Poland, 2014.

26. Polish Std. PN-EN-ISO 10304-1. Jakość Wody-Oznaczanie Rozpuszczonych Anionów za Pomoca Chromatografii jonowej-Czesść 1: Oznaczanie Bromków, Chlorków, Fluorków, Azotanów, Azotynów, Fosforanów i Siarczanów; Wydawnictwa Normalizacyjne: Warszawa, Poland, 2009.

27. Hermanowicz, W.; Dojlido, J.; Dożańska, W.; Koziorowski, B.; Zerbe, J. Fizyczno-Chemiczne Badanie Wody $i$ Ścieków; Wydawnictwo: Warszawa, Poland, 1999.

28. Polish Std. PN-ISO 1928:2002P. Paliwa Stałe-Oznaczanie Ciepła Spalania Metoda Spalania w Bombie Kalorymetrycznej i Obliczanie Wartości Opałowej; Wydawnictwa Normalizacyjne: Warszawa, Poland, 2002.

29. Czop, M.; Błaszczyk, E. Determination of the fuel properties of selected packaging waste from the municipal sector. Arch. Waste Environ. Prot. 2015, 17, 131-138.

30. Wandrasz, J.; Wandrasz, A. Paliwa Formowane Biopaliwa i Paliwa z Odpadów w Procesach Termicznych; Wydawca Seidel-Przywecki Sp. z o.o.: Warszawa, Poland, 2006; pp. 43-78.

31. Przepiórski, J.; Karolczyk, J.; Takeda, K.; Tsumura, T.; Toyoda, M.; Morawski, A.W. Porous carbon obtained by carbonization of PET mixedwith basic magnesium carbonate: Pore structure and pore creation mechanism. Ind. Eng. Chem. Res. 2009, 48, 7110-7116. [CrossRef]

32. García, R.; González-Vázquez, M.P.; Pevida, C.; Rubiera, F. Pelletization properties of raw and torrefied pine sawdust: Effect of copelletization, temperature, moisture content and glycerol addition. Fuel 2018, 215, 290-297. [CrossRef]

33. Fernández, R.G.; García, C.P.; Lavín, A.G.; Bueno de las Heras, J.L. Study of main combustion characteristics for biomass fuels used in boilers. Fuel Process Technol. 2012, 103, 16-26. [CrossRef]

34. Song, E.; Kim, D.; Jeong, C.J.; Kim, D.Y. A Kinetic study on combustible coastal debris pyrolysis via thermogravimetric analysis. Energies 2019, 12, 836. [CrossRef]

35. Földvari, M. Handbook of Thermogravimetric System of Minerals and Its use in Geological Practice; Occasional Papers of the Geological Institute of Hungary: Budapest, Hungary, 2011; p. 63. 
36. Przelaskowska, A.; Klaja, J.; Kulinowski, P.; Gaweł, A. Zastosowanie metod analizy termicznej w badaniach skał silikoklastycznych o zróżnicowanym zaileniu (Thermal analysis of siliciclastic rocks of different clay kontent). Nafta-Gaz 2013, 7, 479-487.

37. Pulka, J.; Manczarski, P.; Koziel, J.A.; Białowiec, A. Torrefaction of sewage sludge, kinetics and fuel properties of biochars. Energies 2019, 12, 565. [CrossRef]

38. Dmitrienko, M.A.; Nyashina, G.S.; Strizhak, P.A. Major gas emissions from combustion of slurry fuels based on coal, coal waste, and coal derivatives. J. Clean. Prod. 2018, 177, 284-301. [CrossRef]

39. Vershinina, K.Y.; Shlegel, N.E.; Strizhak, P.A. Relative combustion efficiency of composite fuels based on of woo processing and oil production wastes. Energy 2019, 169, 18-28. [CrossRef]

40. Chi, H.; Pans, M.A.; Sun, C.; Liu, H. An investigation of lime addition to fuel as a countermeasure to bed agglomeration for the combustion of non-woody biomass fuels in a 20kWth bubbling fluidised bed combustor. Fuel 2019, 240, 349-361. [CrossRef]

41. Michalak, R. Prawne i techniczne aspekty wytwarzania i stosowania paliw z odpadów przemysłowych. In Paliwa z Odpadów; Wandrasz, J.W., Nadziakiewicz, J., Eds.; Wydawnictwo-Helion: Gliwice, Poland, 2003; Volume 4, pp. 21-28.

42. Sobolewski, A.; Ilmurzyńska, J.; Iluk, T.; Czaplicki, A. Zgazowanie biomasy. In Nowoczesne Technologie Pozyskania i Energetycznego Wykorzystania Biomasy; Bocian, P., Golec, T., Rakowski, J., Eds.; Wydawnictwo/Instytut Energetyki: Warszawa, Poland, 2010; pp. 280-309.

43. Pawłowski, P.; Bałazińska, M.; Ignasiak, K.; Robak, J. Przygotowanie odpadów komunalnych do ich energetycznego wykorzystania-Paliwo typu SRF. (Preparation of the selected groups of waste their energy use: Fuel from waste type SRF). Piece Przemystowe Kotty 2016, 4, 21-27.

44. Lebecki, K. Właściwości paliwowe stosowanych w energetyce pyłów pochodzących z biomasy (Combustible characteristics of biomass originating dusts applicable in energy sector). Zeszyty Naukowe Wyższej Szkoły Zarzadzania Ochrona Pracy Katowicach 2010, 1, 71-79.

45. Wisz, J.; Matwiejew, A. Biomasa-badania w laboratorium w aspekcie przydatności do energetycznego spalania. Energetyka 2005, 9, 631-636.

46. Czop, M. Tests of basic fueling properties of polyolefin wastes. Arch. Waste Environ. Prot. 2013, 15, 71-80. [CrossRef]

47. Zakościelna, P.; Sierakowski, M.; Świątkowski, A. Changes in the distribution of heavy metals turing the thermal treatment of municipal sewage sludge (in Polish). Eng. Prot. Environ. 2017, 20, 175-183. [CrossRef]

48. Sładeczek, F. Aktualny stan współspalania paliw z odpadów w piecach cementowych w Polsce. In Proceedings of the I Forum Paliw Alternatywnych, Lubliniec, Poland, 29-30 September 2011.

49. Mokrzycki, E.; Uliasz-Bocheńczyk, A.; Sarna, M. Wastes as alternative fuels in cement industry. In Energy 2000: The Beginning of a New Millenium, Proceedings of the 8-th International Energy Forum ENERGEX 2000, Las Vegas, CA, USA, 23-28 July 2000; Catania, P., Ed.; CRC Press: Boca Raton, FL, USA, 2000; 1421p.

50. Bożym, M. Wymagania jakościowe stawiane osadom ściekowym spalanym w cementowniach. Chemik 2013, 67, 1019-1024.

51. Latkowska, B.; Fitko, H.; Stelmach, S. Ocena właściwości paliwowych ubocznego produktu z produkcji bioetanolu (Evaluation of fuel properties of by-product from bioethanol production). Inżynieria Ekologiczna 2011, 25, 222-230.

52. Polish Std. PN-EN 15359. Stałe Paliwa Wtórne-Wymagania Techniczne i Klasy; Wydawnictwa Normalizacyjne: Warszawa, Poland, 2012.

53. Bilitewski, B.; Härdtle, G.; Marek, K. Podręcznik Gospodarki Odpadami-Teoria i Praktyka; Wydawnictwo-Seidel-Przywecki: Warszawa, Poland, 2006; pp. 454-455.

54. Manzone, M.; Gioelli, F.; Balsari, P. effects of different storage techniques on round-baled orchard-pruning residues. Energies 2019, 12, 1044. [CrossRef]

55. Poluszyńska, J. Możliwości zastosowania popiołów ze spalania biomasy w gospodarowaniu osadami ściekowymi. Prace Instytutu Ceramiki Materiałów Budowlanych 2013, 13, 49-59.

56. Ciesielczuk, T.; Kusza, G.; Nemś, A. Nawożenie popiołami z termicznego przekształcania biomasy źródłem pierwiastków śladowych dla gleb. Ochrona Środowiska Zasobów Naturalnych 2011, 49, $219-227$.

57. Pachowski, J. Popioły Lotne i Ich Zastosowanie w Budownictwie Drogowym; Wydawnictwa Komunikacji i Łaczności: Warszawa, Poland, 1976. 
58. Wang, S.; Miller, A.; Llamazos, E.; Fonseca, F.; Baxter, L. Biomass fly ash in concrete: Mixture proportioning and mechanical properties. Fuel 2008, 87, 365-371. [CrossRef]

59. Hinojosa, M.J.R.; Galvin, A.P.; Agrela, F.; Perianes, M.; Barbudo, A. Potential use of biomass bottom ash as alternative construction material: Conflictive chemical parameters according to technical regulations. Fuel 2014, 128, 248-259. [CrossRef]

60. Meller, E.; Bilenda, E. Wpływ nawożenia popiołami z biomasy na plon i pobranie składników przez kukurydze zwyczajną. Polityka Energetyczna 2013, 16, 339-345.

61. Vassilev, S.V.; Baxter, D.; Andersen, L.K.; Vassileva, C.G. An overview of the composition and application of biomass ash-Part 1: Phase-mineral and chemical composition and classification. Fuel 2013, 105, 40-76. [CrossRef]

62. Querol, X.; Moreno, N.; Umaña, J.; Alastuey, A.; Hernández, E.; López-Soler, A.; Plana, F. Synthesis of zeolites from coal fly ash: An overview. Int. J. Coal Geol. 2002, 50, 413-423. [CrossRef]

63. Minister of Economy (Poland). Regulation of the Minister of Economy of 16th July 2015 on the Admission of Waste for Landfills; (in Polish: Rozporzadzenie Ministra Gospodarki z dnia 16 lipca 2015 r. w sprawie dopuszczania odpadów do składowania na składowiskach, Dz.U. 2015 poz. 1277); Minister of Economy: Warsaw, Poland, 2015.

(C) 2019 by the authors. Licensee MDPI, Basel, Switzerland. This article is an open access article distributed under the terms and conditions of the Creative Commons Attribution (CC BY) license (http://creativecommons.org/licenses/by/4.0/). 